\title{
Initial Science Report of Shallow Drilling Penetrating into the Chelungpu Fault Zone, Taiwan
}

\author{
Hidemi Tanaka ${ }^{1}$, Chien-Ying Wang ${ }^{2, \star}$, Wei-Min Chen ${ }^{2}$, Arito Sakaguchi ${ }^{3}$, \\ Kotaro Ujiie ${ }^{3}$, Hisao Ito $^{4}$, and Masataka Ando ${ }^{5}$
}

(Manuscript received 1 March 2002, in final form 8 July 2002)

\begin{abstract}
The Chelungpu fault, a reverse fault with left lateral component dipping moderately to the east, was activated by the Chi-Chi earthquake $(\mathrm{Mw}=7.6)$ in 21 September, 1999 with maximum vertical and lateral offsets of $5.6 \mathrm{~m}$ and $9.8 \mathrm{~m}$. Characteristics of earthquake and related phenomena are contrasting between northern and southern regions along the Chelungpu fault. The northern region has (1) larger displacements (4 to $9 \mathrm{~m}$ ), (2) low frequency seismic waves with higher velocity of slip surface, and (3) less disastrous except the most northern area compared to those in the southern region. Drilling into the Chelungpu fault was thus conducted at two locations, northern (Fengyuan) and southern (Nantou) sites, and successfully completed in March 2001. The project was motivated to explore the fundamental controlling factors of the mode of slip motion at northern and southern regions through analysis of intrafault materials.

Meso- and microstructural examinations and measurements of static/ dynamic physical properties have been conducted for each drill core. The ongoing analyses have shown interesting results: (1) fault zone architecture is totally different between the northern and southern fault zones. The rocks are mainly composed of random fabric fault breccia with extremely thin fault gouge in the northern core, whereas the foliated fault breccia is dominantly associated with ultracataclasite and pseudotachylite in the southern core, (2) possible fault zones activated by the Chi-Chi earthquake can be listed up by combining geological, geophysical logging and reflection seismic data, which are $225 \mathrm{~m}$ and 330 fracture zones in the core from northern well and $177 \mathrm{~m}$ and $180 \mathrm{~m}$ fracture zones in the core from southern
\end{abstract}

\footnotetext{
${ }^{1}$ Department of Earth Science, University of Tokyo, Tokyo, Japan

${ }^{2}$ Institute of Geophysics, National Central University, Chung-Li, Taiwan

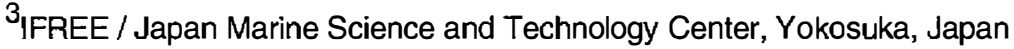

${ }^{4}$ Geological Survey of Japan, AIST, Tsukuba, Japan

${ }^{5}$ Research Center for Seismology and Volcanology, Nagoya University, Nagoya, Japan

${ }^{\star}$ Corresponding author address: Prof. Chien-Ying Wang, Institute of Geophysics, National Central University, Chung-Li, Taiwan, ROC; E-mail: wangcy@cc.ncu.edu.tw
} 
well, (3) water contents of the core of the $225 \mathrm{~m}$ rupture zone in the northern well attains up to 45 vol. \%, and (4) some temperature rises were detected at $330 \mathrm{~m}$ fracture zone in the northern well and $180 \mathrm{~m}$ fracture zone in the southern well by temperature logging, which could be attributed to residual heat generated during the Chi-Chi earthquake or postseismic influx of hydrothermal fluid into the fault zones.

\section{(Key words; Chi-Chi earthquake, Active fault zone drilling, Core analysis, Chelungpu fault, Multi-disciplinary research)}

\section{INTRODUCTION}

An Mw 7.6 earthquake (Chi-Chi earthquake) occurred on the 21 September 1999, Taiwan accompanied with surface rupture extending more than $80 \mathrm{~km}$ along the Chelungpu fault. This earthquake has three major characteristics. (1) The largest displacement of about $9 \mathrm{~m}$ was observed at the northern portion along the Chelungpu fault with damages limited within hundreds of meters from the surface rupture. In contrast, the most severe disasters of building desructions, extensive landslides and loss of human lives were more distributed in the southern region along the fault. However, the surface displacement of the fault was much smaller in the south than that in the north (1 to $4 \mathrm{~m}$ ). (2) Seismic records along the fault indicate that high frequency wave components dominate the southern portion, and gradually attenuated toward the north where lower frequency wave components were dominated (Tsai and Huang 1999; Ma et al. 1999). This observation suggests that dynamic motion of the fault surface was rapid but very smooth at the northern portion. (3) Inversion analysis (Ma et al. 2000) indicates that northern portion of the Chelungpu fault was activated about 10 seconds after rupturing in the southern portion, suggesting that the fault slip at north was triggered by the fault movement from the south.

The seismic characteristics in the southern region along the Chelungpu fault are similar to those of general inland earthquakes, such as the 1995 Hyogoken-Nanbu earthquake, whereas those in the northern region are somewhat similar to the Tsunami earthquakes that are generally observed in subduction zones (Seno 2000). Thus, the Chi-Chi earthquake could be characterized by a mixture of inland and subduction zone "Tsunami" earthquakes and the latter could be triggered by the former. If this is the case, the northern and southern fault zones may have contrasting mechanical, chemical, and physical characteristics. The fundamental purpose for drilling into the Chelungpu fault zone is, therefore, to understand these characteristics through material analysis of fault rocks. The northern fault zone is especially important, because highquality seismic records coupled with direct observation of fault zone material recovered from the borehole may help to improve our knowledge of the generation mechanism of Tsunami earthquakes.

Whole-coring drill penetrating the fault zone is essential to improve our understanding of the following four issues concerning the fault zone architecture: (1) the entire fault zone structure and fault rock distribution, (2) estimation of velocity and possible heat generation on the 
fault surface during the co-seismic slip, (3) mode of strain localization which results in high velocity motion and thus heat generation by mechanical wearing along the fault surface and (4) the fluid path and permeability distributions in the fault zone. It would be difficult to complete these researches without drilling, because dynamic motions generally occur within narrow fault zones of cms to $1 \mathrm{~m}$ in thickness (Chester et al. 1993; Tanaka et al. 2001a), which would be too narrow to be analyzed by common seismological methods. The surface outcrops of the fault zone are generally limited and, if present, are generally modified by weathering since these rocks are extremely soft and fragile, which are easily altered and eroded. The continuous coring will provide us a good opportunity to observe and analyze a complete succession of the fresh fault zone rocks soon after a large earthquake.

The Chelungpu drilling project was funded mostly by JSTA (Japan Science and Technology Agency, now reorganized as MEXT), as a Taiwan and Japan co-operative project in April 2000. Similar projects have been conducted recently in Japan, the "Fault Zone Probe" for the Nojima fault, which was activated in the 1995 Hyogoken-Nanbu earthquake $(M w=6.9)$ (Ando 2001), and the currently underway "Frontiers in Monitoring Science and Technology for Earthquake Environments" for the Mozumi-Sukenobu Fault in central Japan to investigate the creeping mode at a certain depth of the fault (Ando, in review). The core material analysis in these projects produces excellent results including great improvement of our understanding for fault zone structure and dynamic processes of fault zone in the seismic cycle (e.g., see special issue for "Fault zone probe" 2001).

\section{TECTONIC SETTINGS AND GEOLOGY SURROUNDING THE CHELUNGPU FAULT}

Taiwan is located at a boundary between the Eurasian and the Philippine Sea plates, where the former is subducting or colliding from west to east (Suppe 1981; Wang et al. 2000), while the latter is also subducting from southeast to northwest. The east-west compression produces high-elevated mountain ranges running almost $\mathrm{N}-\mathrm{S}$ throughout the island. The mountain ranges have been uplifted mostly by displacements of thrust faults dipping moderately to the east. The tectonic framework of Taiwan is modeled based on deep seismic reflection study and ultra-deep drilling performed by the Chinese Peroleum Corporation (CPC) (Suppe et al. 1985). They suggest that the thrust faults bounding the geological units are derived from a low-angle master decollement at depth, which could have a similar role of subduction thrust faults, such as out-of-sequence thrusts (thin skinned model: Suppe 1981; Wang et al. 2000). Another hypothesis is that the collision between the Eurasian and the Philippine Sea plates is bounded by the Longitudinal Valley (Wu et al. 1997; Angelier et al. 1997; Lallemand 2000). This is based mainly on the fact that micro-seismicity is distributed ambiguously and does not coincide with the shape of subducting slab beneath the western foothill area. These two hypotheses are still controversial, although these are not directly concerned with the dynamic motion of the 1999 Chi-Chi earthquake.

The geological trend in Taiwan is roughly N-S bounded mostly by thrust faults dipping moderately to the east. The younger sediments are distributed to the west, as the older weakly metamorphosed rocks in the middle, and the oldest high-P/T metamorphic rocks to the east. 
Gently sloping hills and basins, also trending N-S, characterize the geomorphology of western part of Taiwan (western foothill area), where younger unconsolidated sediments are exposed. The Chelungpu fault and the Changhua fault are the active thrust faults bounding the western base of such hills (Fig. 1).

Two drilling sites at Fengyuan and Nantou are located within western foothill area and are $60 \mathrm{~km}$ apart from each other (Fig. 1). The lithofacies and geological structure are similar at both sites as these two sites are located within similar structural units. This is an advantage for comparing the fault zone structures and materials between both wells.

Geological units at both sites consist of several lithofacies, from younger to older, Pleistocene Toukoshan Formation (unconsolidated gravels), late Pliocene Cholan Formation (sandstone dominant alternation), early Pliocene Chinshui Formation (mudstone dominant alternation) and early Pliocene to late Miocene Kueichulin Formation (alternating beds of

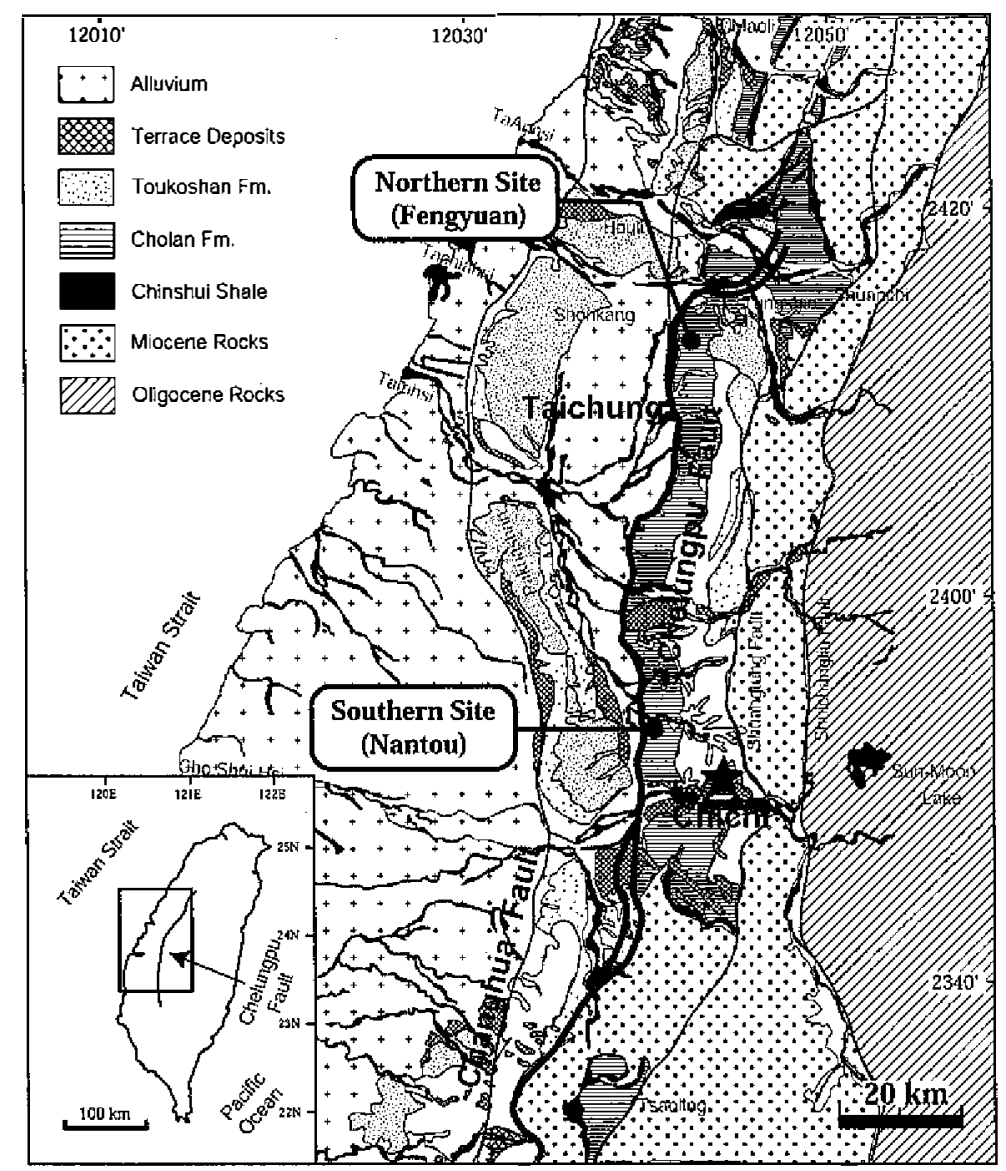

Fig. 1. Geological map of central Taiwan modified after Wang et al. (2000). The northern (Fengyuan) and southern (Nantou) drilling sites are also indicated. 
sandstone and mudstone). Detailed stratigraphy and lithofacies are described in Ho (1997).

\subsection{Outline Explanations of Drilling}

Two sites were selected for fault zone drilling; one is located at Fengyuan city (referred here after to as the northern site) and the other is at Nantou city (the southern site). Shallow seismic reflection survey was conducted to estimate the trace of earthquake ruptures at depth and necessary drilling length to the fault zones from the sites (Wang et al. 2002). Drilling is conducted with recovering HQ sized core ( $62 \mathrm{~mm}$ in diameter) by the wire-line method. At the northern site, drilling was performed at an angle of 50 degrees to the west and was stuck at the depth of $293 \mathrm{~m}$. Side tracking with the same diameter and direction with the initial hole was then performed from the depth of $207.50 \mathrm{~m}$ to the bottom $(455.30 \mathrm{~m})$. It appears to penetrate successfully the possible earthquake rupture zones at the depth of $225 \mathrm{~m}$ and $330 \mathrm{~m}$ (drilling depths). The shallower fracture zone (225 m depth) is composed of relatively narrow ( $3 \mathrm{~m}$ maximum), high-water content, fragile fault breccia originated from sandstones of Chinshui or Kueichulin Formation. The borehole was extremely unstable around that depth. The deeper fracture zone ( $330 \mathrm{~m}$ depth) is composed of more consolidated, thick $(>10 \mathrm{~m})$ fault breccia with very thin $(<1 \mathrm{~cm})$ slip zone mainly composed of fine-grained clay minerals. The depths of two fracture zones coincide well with those deduced from the results of shallow seismic reflection survey (Fig. 2; Wang et al. 2002).

At the southern site, the vertical drilling well successfully penetrated the fault surface around $177 \mathrm{~m}$ depth. The fault zone is composed of relatively consolidated, thick $(>50 \mathrm{~m})$, foliated fault breccia accompanying with about $3 \mathrm{~m}$ thick, dark gray colored, ultracataclasites. The fault surface bounds the Chinshui Formation at the hanging wall and the Toukoshan gravels at the footwall. It coincides with that interpreted from the seismic reflection data, suggesting that the 1999 earthquake rupture exists around the $177 \mathrm{~m}$ fracture zone.

After the drilling mission, the core materials are open to Taiwan, Japan and U.S. researchers by holding core-sampling parties in March and April 2001. Combining the results together with various kinds of geophysical/geological data will bring us better understandings on the generation mechanisms of the Chi-Chi earthquake.

\subsection{Northern Site}

The northern drilling site is about $2.1 \mathrm{~km}$ ENE from Fengyuan city and is about $500 \mathrm{~m}$ offset to the east of surface rupture of the Chelungpu fault (Fig. 2a). The maximum displacement of surface rupture attains up to $9 \mathrm{~m}$ in this area, which is one of the largest displacements along the whole trace of the surface rupture along the Chelungpu fault. Geological unit around the drilling site is composed of sedimentary rocks of Chinshui Formation (>150 $\mathrm{m}$ in thickness) and Kueichulin Formation ( $300 \mathrm{~m}$ in thickness), dipping moderately (30 to 40 degree) to the east. Although the lithofacies of both formations are similar and difficult to distinguish by visual observation, detailed analysis of sedimentary facies along with microfossil examination clarify the exact boundary between these two formations (Hung et al. 2001). 

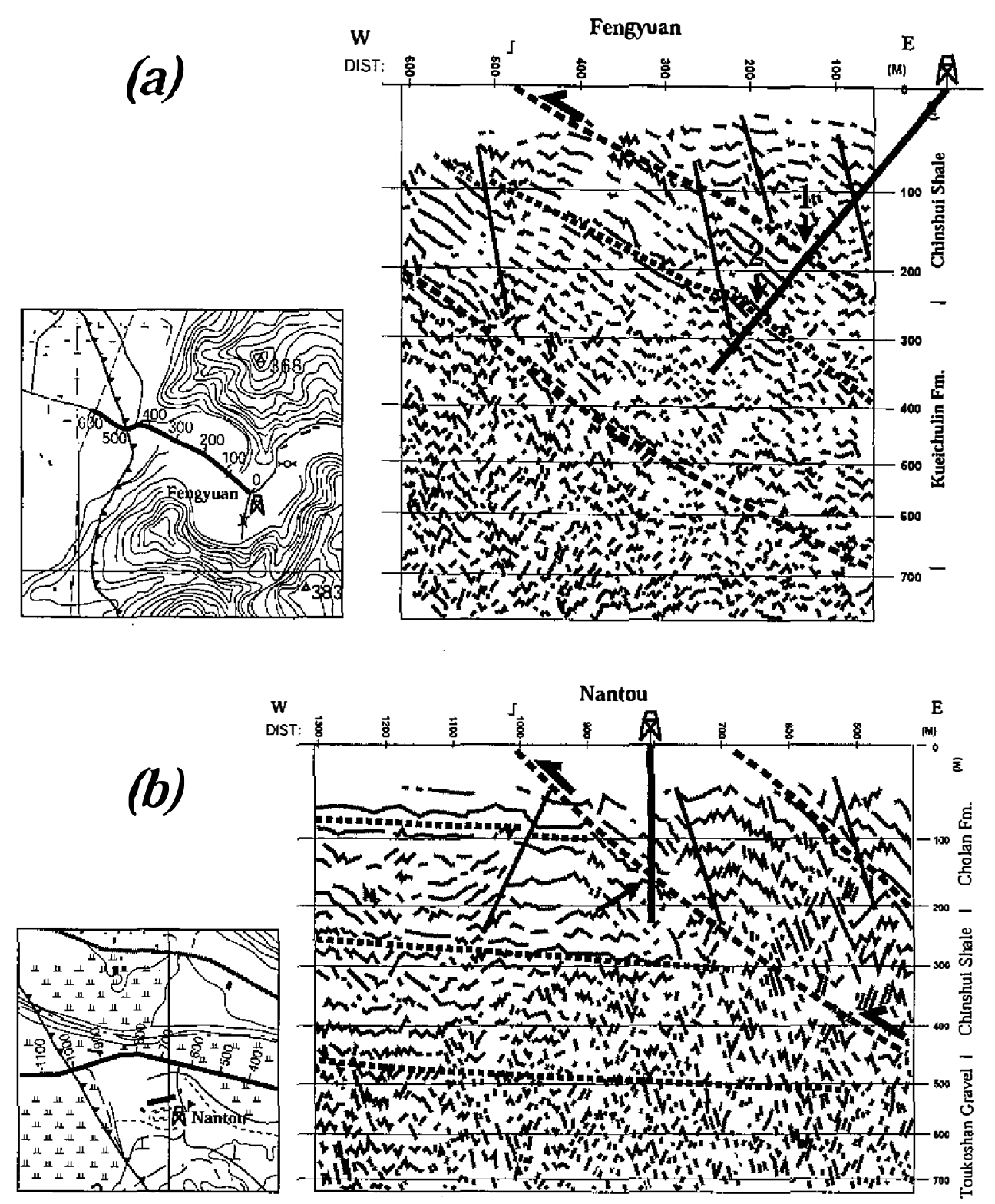

Fig. 2. Interpretations of shallow seismic reflections, modified after Wang et al. (2002). (a) the northern site, drilling angle is $50^{\circ}$ from the surface to the west. The arrow ' 1 ' points to the N-MFZ-1 fracture zone (225 m drilling depth), and the arrow '2' points to the N-MFZ-2 fracture zone (330 m drilling depth). (b) the southern site, arrow points the S-MFZ fracture zone (177 $\mathrm{m}$ drilling depth). The depths of the major fracture zones observed in the core correlate well with the interpretation. See Figs. 4 and 5 for detailed locations of fracture zones indicated in this figure. 
Results of shallow reflection survey indicate that the active trace of the Chelungpu fault beneath the surface lies parallel to and between the Chinshui and Kueichulin Formations (Fig. 2a) dipping at 40 degrees to the east (Wang et al. 2002). The hanging wall strata are disturbed with drag folds and minor reverse faults. The results also suggest the existence of another deeper thrust fault within the Kueichulin Formation, which also lies parallel to the strata. This fault is probably activated by the 1999 Chi-Chi earthquake as described later. At further depth, a larger thrust fault also lies parallel to the overlying strata, and seems to bound the Kueichulin and the Toukoshan Formations. This thrust fault would have experienced the largest displacement because the older Kueichulin Formation thrust over the younger Toukoshan gravels. Further more, this fault could be a master decollement for the surface ruptures along the Chelungpu fault. However, the details are unknown because the borehole could not reach to that fault. The results of ultra-deep drilling conducted by CPC suggest the base of the Toukoshan Formation lies horizontally at $2000 \mathrm{~m}$ beneath the surface, suggesting that the net vertical displacement of the master thrust fault between the Kueichulin and Toukoshan Formations attains at least $3000 \mathrm{~m}$.

\subsection{Southern Site}

The southern drilling site is at $2.5 \mathrm{~km}$ southeast of Nantou city and is about $250 \mathrm{~m}$ offset to the east from the earthquake surface rupture (Fig. 2b). The vertical displacement of surface rupture is about 1 to $2 \mathrm{~m}$ in this area. Geological units exposed at the surface around the drilling site are composed of sedimentary rocks of Cholan (>150 m thick) and Chinshui (200 $\mathrm{m}$ thick) Formations showing monoclinic structure dipping moderately to the east. The Kueichulin Formation is not present beneath the Chinshui Formation in this area. Instead, gravel layers of the Toukoshan Formation are shown beneath the Chinshui Formation. Results of shallow seismic reflection survey suggest that the rupture zone activated by the Chi-Chi earthquake coincides with the Chelungpu fault which lies between the Chinshui and Toukoshan Formations, dipping 38 degree to the east. The Chelungpu fault is the major thrust fault in this region thrust the older Chinshui Formation over the younger Toukoshan Formation.

\section{DETAILED DESCRIPTIONS OF THE DRILL CORES}

First, the cores recovered from the wells are washed to remove the drilling mud sticking on the surfaces of the cores. After photographs were taken and the lithofacies and meso-, micro-structures were described (Fig. 3), the color spectrum data are sampled from core surfaces.

The fracture zones in the core are extremely soft and fragile, thus these portions are protected with plastic tubes to prevent from drying out and breaking down. The total length of the drilled core recovered from the northem well is $540.85 \mathrm{~m}$ ( 0 to $293.15 \mathrm{~m}$ for BH-1 and 207.60 to $455.30 \mathrm{~m}$ for BH-1A) and $211.20 \mathrm{~m}$ (CLF-2) for the southern well. Mode of distribution of fault zone rocks is examined based on detail descriptions of the drilled cores (Figs. 4 and 5). Then, the cores of the fracture zones are fixed by resin and cut into three pieces following to the method of Tanaka et al. (2001) at the Exploration and Development Research Institute (EDRI), CPC, Miaoli. 



Fig. 3. Diagram showing detail descriptions and sketches of core \#. This work has been underway for all other recovered cores.

Terminology related to the classification of fault rocks and their textures, for example, fault breccia, fault gouge, 'foliated' and 'random fabric', are followed by Sibson (1977), Tanaka (1992), Tanaka et al. (1995), and Tanaka et al. (2001a).

\subsection{Description of Cores Recovered from the Northern Site}

There are two boreholes in the northern site (Fig. 4); one is from the surface down to the depth of $293.15 \mathrm{~m}$ (BH-1), and the other is the side track from $207.50 \mathrm{~m}$ in $\mathrm{BH}-1$ to the depth of $455.30 \mathrm{~m}$ (BH-1A). In other words, the depth range from 207.5 to $293.15 \mathrm{~m}$ has been taken twice. Core description is based on the BH-1 core from the surface to $207.5 \mathrm{~m}$ and the BH-1A core from $207.5 \mathrm{~m}$ to the bottom $(455.30 \mathrm{~m})$.

Surface soil has a thickness of $2.4 \mathrm{~m}$ from the surface. A $1.4 \mathrm{~m}$ thick, unconsolidated gravel layer lies beneath the surface soil. The Chinshui Formation is distributed from $3.8 \mathrm{~m}$ to around $225 \mathrm{~m}$ depth (Hung et al. 2001). The Chinshui Formation is mainly composed of dark gray siltstone, accompanying with fine-grained sandstone, alternated sandstone and siltstone 

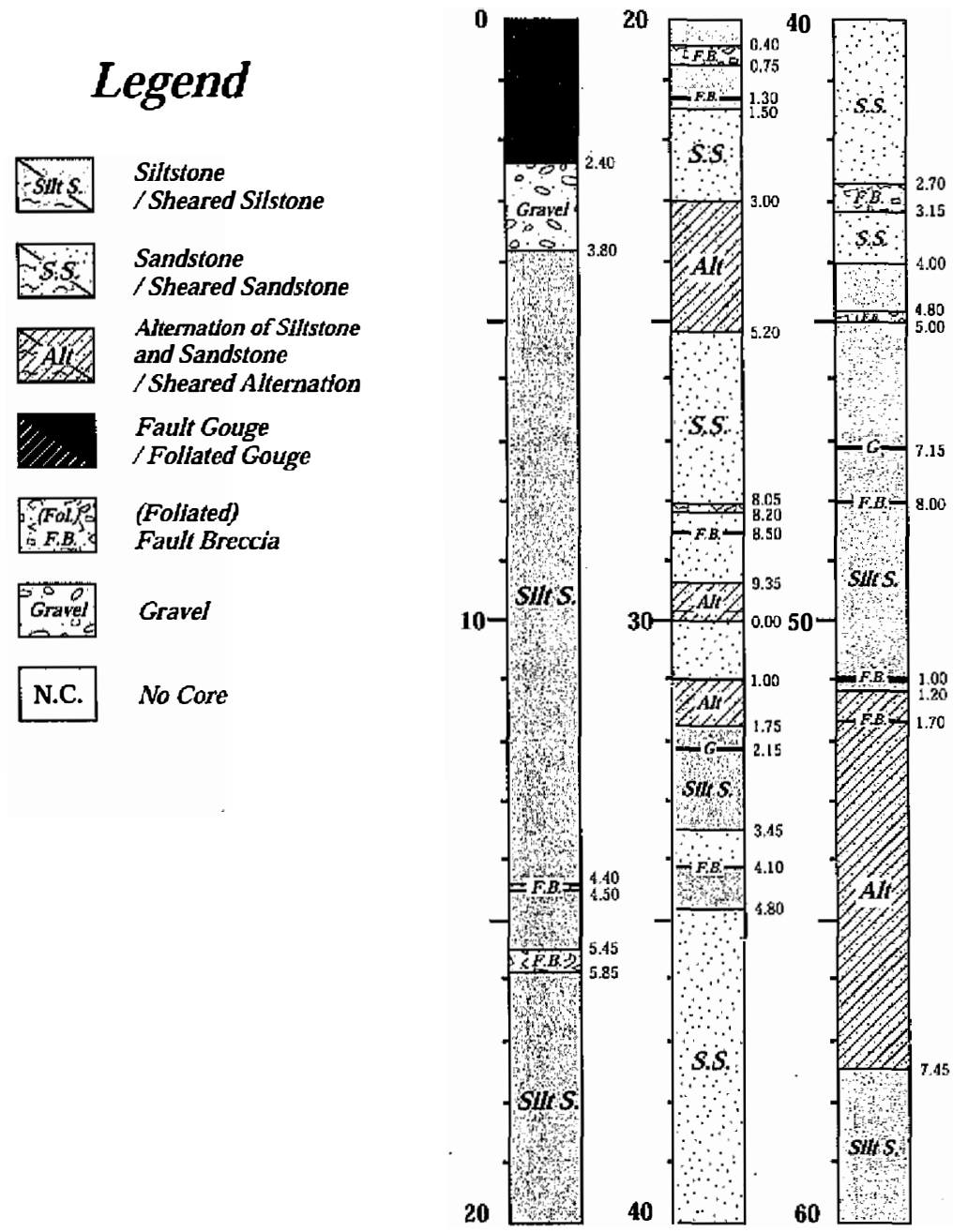

\section{Northern Borehole BH-1 1/3}

Fig. 4. Columnar section showing lithology and fault rock distributions in the cores (BH-1 and BH-1 A) recovered from the northern (Fengyuan) well.

(Fig. 6a). Sedimentary facies are well preserved from $3.8 \mathrm{~m}$ to $142 \mathrm{~m}$ depth, although minor (< $1 \mathrm{~m}$ thick) fault breccia zones are sparsely distributed. There are several coarse-grained sandstone layers, which are characterized by higher porosity and lower consolidation, at the depth around $130 \mathrm{~m}$ where the recovery rate of the core is quite low. From $142 \mathrm{~m}$ to $149.4 \mathrm{~m}$ depth, more than 10 layers of fault breccia and fault gouge, which are commonly less than $1 \mathrm{~m}$ in thickness, constitute a fracture zone (N-UFZ-1). The fault breccia typically shows random fabric textures. The undeformed siltstone is distributed from $165.0 \mathrm{~m}$ to $216.9 \mathrm{~m}$, although 

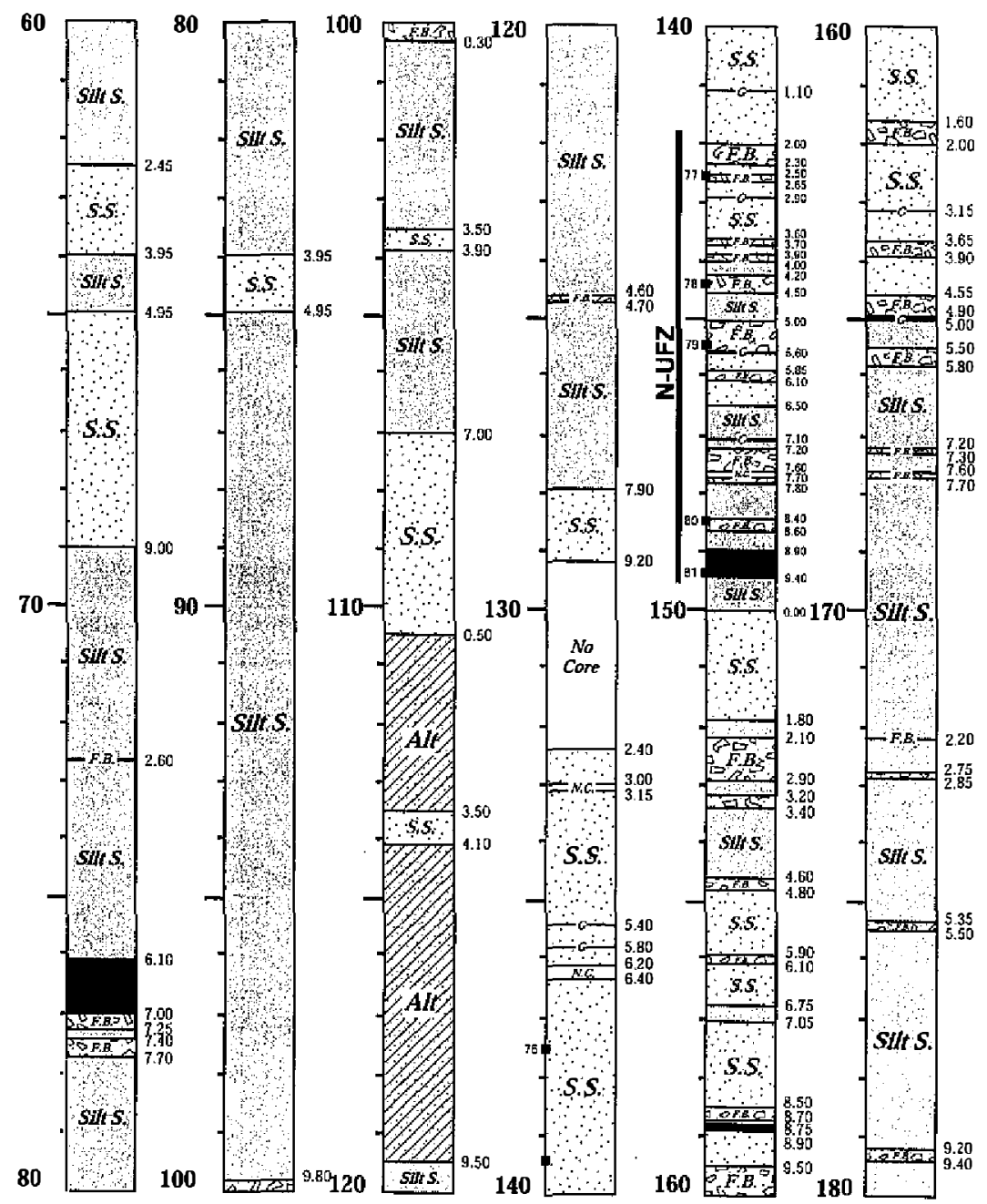

\section{Northern Borehole BH-1 2/3}

(Fig. 4. continued)

thin layers of fault breccia and fault gouge, cm order in thickness, are sparsely intercalated. Beneath $194.8 \mathrm{~m}$ drilling depth, the host rocks become more consolidated and change gradually to sandstone dominant facies.

The $20 \mathrm{~cm}$ thick unconsolidated fault breccia zone from $224.55 \mathrm{~m}$ to $224.75 \mathrm{~m}$ shows specific characteristics (N-MFZ-1 in Figs. 4 and 6b). The upper and lower boundaries are planar surfaces juxtaposing the fault breccia and host rock sandstones. Water content of the fault breccia was measured immediately after recovering, which attains up to 45 vol.\%. Clasts included in the fault breccia are $2 \mathrm{~mm}$ to $2 \mathrm{~cm}$ in diameter, and show angular shape with sharp 




\section{Northern Borehole BH-1 3/3}

(Fig. 4. continued)

edges. The matrix is mainly composed of self-crushed fine-grained materials with high water contents. Microfossil examination clarified that facies boundary between the Chinshui and Kueichulin Formations exists around the fault breccia zone (Hung et al. 2001).

The coarse grained sandstones, which are less consolidated compared to the surrounding host rocks, lie just beneath the fault breccia zone from $225.30 \mathrm{~m}$ to $225.70 \mathrm{~m}$. This part of the sandstone is hardly recovered as well as those around $130 \mathrm{~m}$. From $227.0 \mathrm{~m}$ to $285.4 \mathrm{~m}$, the lithofacies are mainly undeformed sandstone, associated with alternated sandstone and sandy 


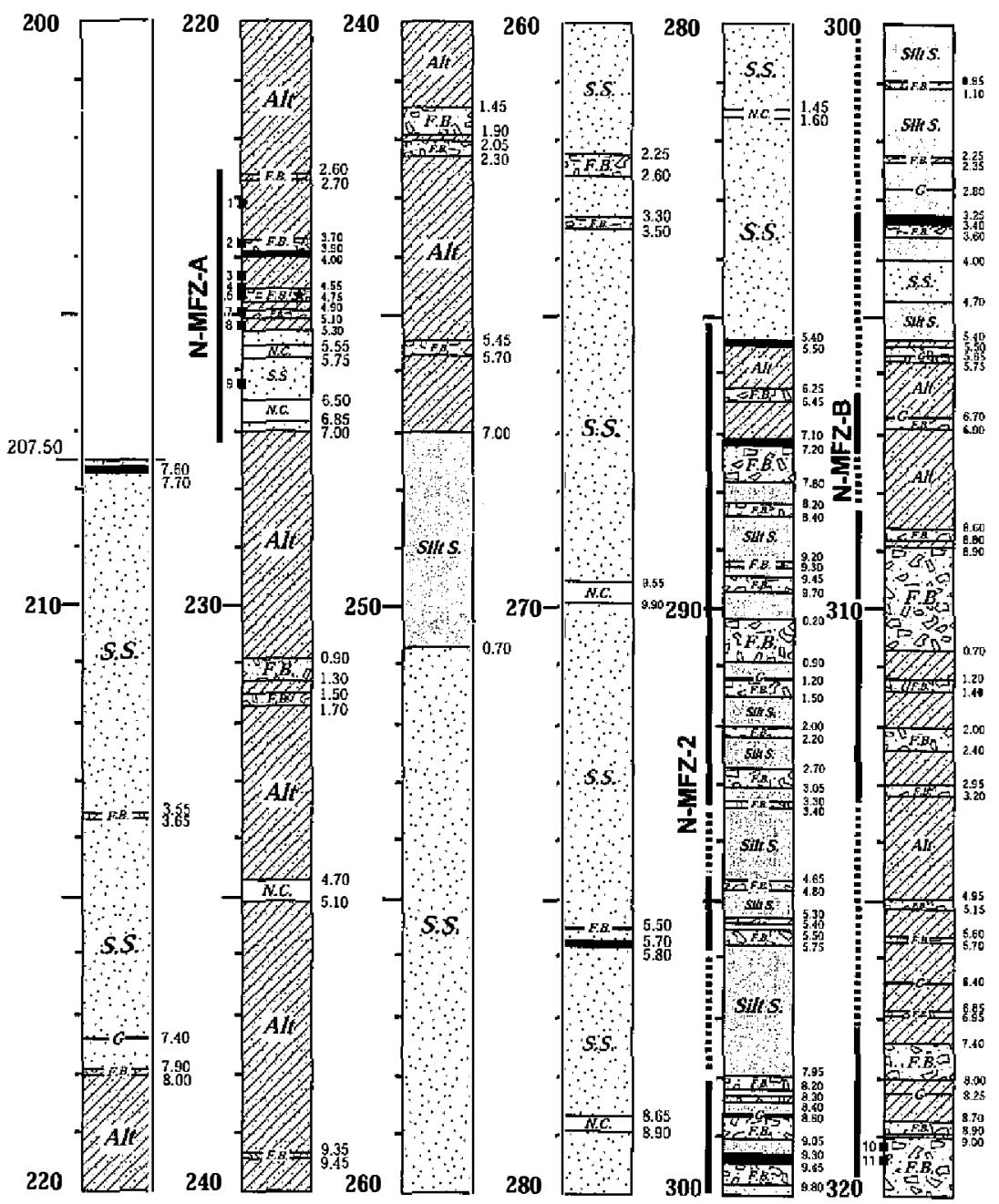

\section{Northern Borehole BH-1A 1/2}

(Fig. 4. continued)

siltstone.

The thickest fracture zone (N-MFZ-2) has been observed from $285.40 \mathrm{~m}$ to $329.65 \mathrm{~m}$. Thin fault breccia zones, commonly less than $1 \mathrm{~m}$ in thickness, are concentrated, and are associated with thinner fault gouge layers ( $<10 \mathrm{~cm}$ in thickness) in the upper half $(285.40 \mathrm{~m}$ to $318.00 \mathrm{~m}$ ) of the N-MFZ-2 zone. Cracks and shear surfaces are predominant even in the relatively undeformed sedimentary rocks in this depth range. The lower half of this zone (318.70 $\mathrm{m}$ to $329.65 \mathrm{~m}$ ) is composed mostly of random fabric fault breccia (Fig. 6c). A $7 \mathrm{~mm}$ thick fault gouge layer lies at the bottom of the fault breccia zone (329.65 m depth, Figs. $2 \mathrm{~b}$ and 6c), 


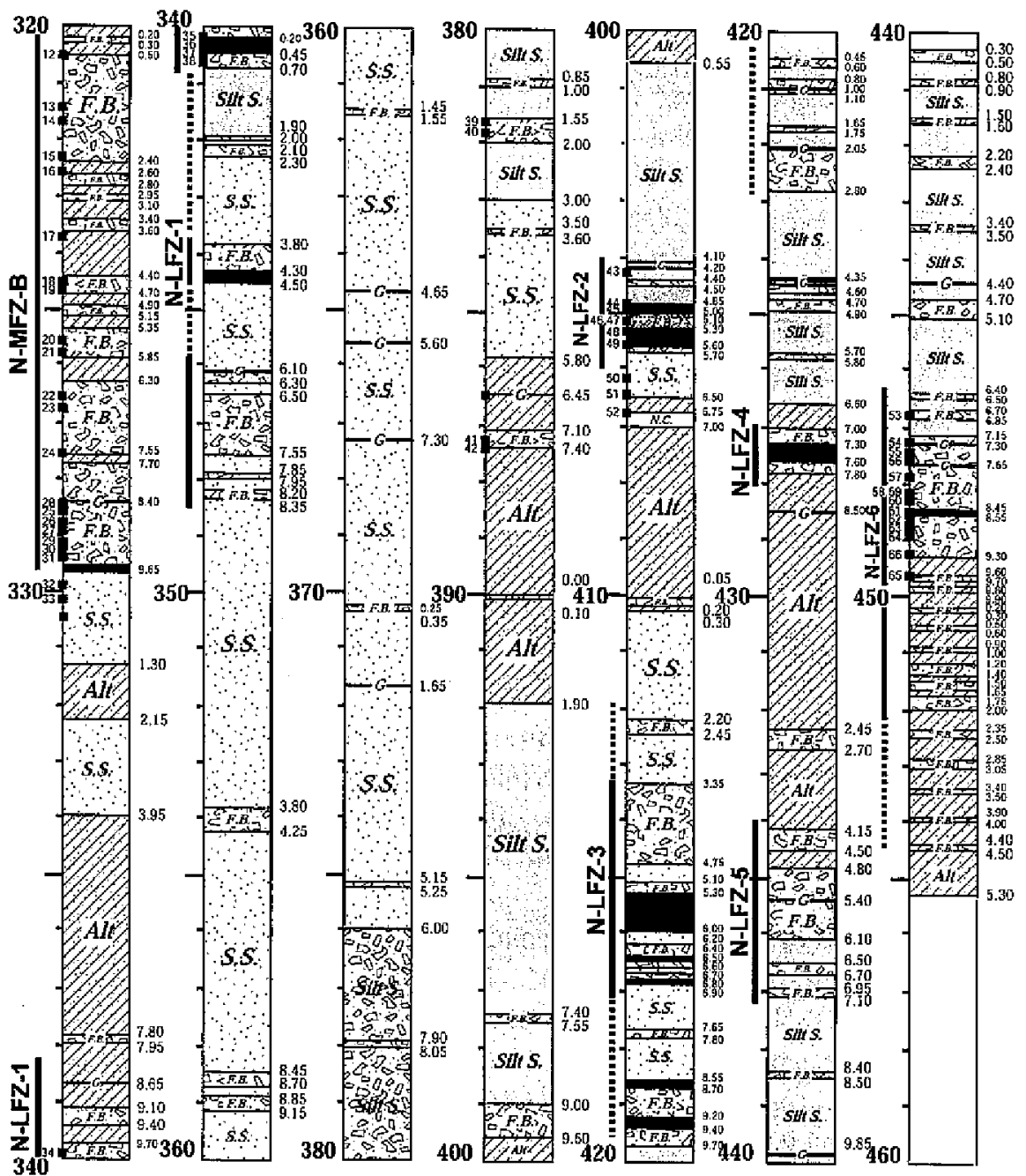

Northern Borehole BH-1A 2/2

(Fig. 4. continued)

which bounds the N-MFZ-2 fracture zone and host sedimentary rocks.

The cores ranging from $329.65 \mathrm{~m}$ to $376.00 \mathrm{~m}$ are dominantly composed of relatively undeformed sandstone, although some thin layers of fault breccia and fault gouge are observed. Beneath $376.00 \mathrm{~m}$, content of siltstone gradually increases towards the bottom of the core. Six layers of fault breccia zones (N-LFZ-1 to -6) are observed in this range (Fig. 4), each of which has 1 to $5 \mathrm{~m}$ in thickness and shows basically random fabric texture. Among these, the fracture zone ranging from $404.1 \mathrm{~m}$ to $405.7 \mathrm{~m}$ (N-LFZ-2) contains a $50 \mathrm{~cm}$ thick fault gouge layer, which intervenes two layers of $1 \mathrm{~mm}$ thick, dark gray, ultra-fine grained materials (Fig. 6d). 
Preliminary microscopic observation shows that these two layers are mainly composed of very fine grained, oriented clay particles (Fig. 6e). Thus, although occurrence of the layers are similar to that of the pseudotachylite, a few evidence is confirmed for melting and rapid cooling within the layers.

\subsection{Description of the Core Recovered from the Southern Site}

The core material was almost completely recovered from the southern borehole (CLF-2) from 0 to $211.2 \mathrm{~m}$ depth (Fig. 5). Generally speaking, the degree of consolidation of the sedimentary rocks (the Chinshui Formation) is lower than that from the northern borehole. The distinct structural characteristics of the core materials from the southern borehole are that they are sheared and fractured at a shallower depth and the shear zones are mostly composed of 'foliated' fault breccia and fault gouge. Only a few portions are undamaged throughout the entire core. The host rocks in the southem borehole are more or less sheared and the boundary between the host and fault rocks is gradual.

The brown soil is distributed from the surface to $8.65 \mathrm{~m}$ depth, and the underplayed sedimentary rocks (sandstone, alternated sandstone and siltstone) in the Chinshui Formation are distributed down to $177.68 \mathrm{~m}$ depth. Five fracture zones (S-UFZ-1 to -5), containing foliated fault breccia, $30 \mathrm{~cm}$ to $3 \mathrm{~m}$ thick, are present from $8.65 \mathrm{~m}$ to $76.9 \mathrm{~m}$. The foliated fault breccia is characterized by flow textures associated with minor Riedel and $P$ shear surfaces along the foliations (Fig. 6f). Foliations discriminated by flow textures tend to be at 30 to 60 degrees to the horizontal surface. From $76.9 \mathrm{~m}$ to $103.9 \mathrm{~m}$, the core is mainly composed of less damaged alternated sandstone and siltstone.

There are four zones of foliated fault breccia, each of which is about $10 \mathrm{~m}$ thick from 103 . $90 \mathrm{~m}$ to $176.80 \mathrm{~m}$ (S-UFZ-6 to -8 , and S-MFZ). These fracture zones are characterized by the presence of thick $(>1 \mathrm{~m})$ foliated fault gouge. The thickest fracture zone exists at 153.6 to 176 . $8 \mathrm{~m}$ (S-MFZ), which is mostly composed of foliated fault breccia (Fig. 6f) associated with a 1. $1 \mathrm{~m}$ thick foliated fault gouge near the bottom $(173.8$ to $174.9 \mathrm{~m})$. The clasts in the fault gouge ( 0.5 to $3 \mathrm{~cm}$ in diameter) are mostly subangular to rounded sandstones, surrounded by clay dominant matrix well oriented parallel to the long axes of the clasts. This flow pattern is similar to the stokes flow with small R number (<1.0, e.g., Tanaka et al. 2001a).

The dark gray fine-grained material is distributed from $174.9 \mathrm{~m}$ to $176.8 \mathrm{~m}$, overlain by a foliated fault gouge in the S-MFZ (Fig. 6g), although part of this portion was not recovered. The dark gray material is composed of aggregates of angular micrograins, generally 0.5 to 2 $\mathrm{mm}$ in diameter. This portion of the core is extremely fragile, even easily decomposed when touched by fingers. Preliminary microscopic observations suggest that this material basically shows a random fabric texture, in which the clasts are composed of small amounts of very fine-grained quartz-feldspar and the matrix is mostly composed of cryptocrystalline dark colored materials with minor amounts of clays (Fig. 6h). The occurrence of this material is similar to that of ultracataclasites. Ohtsuki and Monzawa (2001) reported that the ultracataclasites partly associate with pseudotachylite, suggesting that this zone was closely related to seismic, high velocity frictional slip as well as heat generation.

The Toukoshan Formation is distributed below $177.3 \mathrm{~m}$ depth to the bottom of the core 

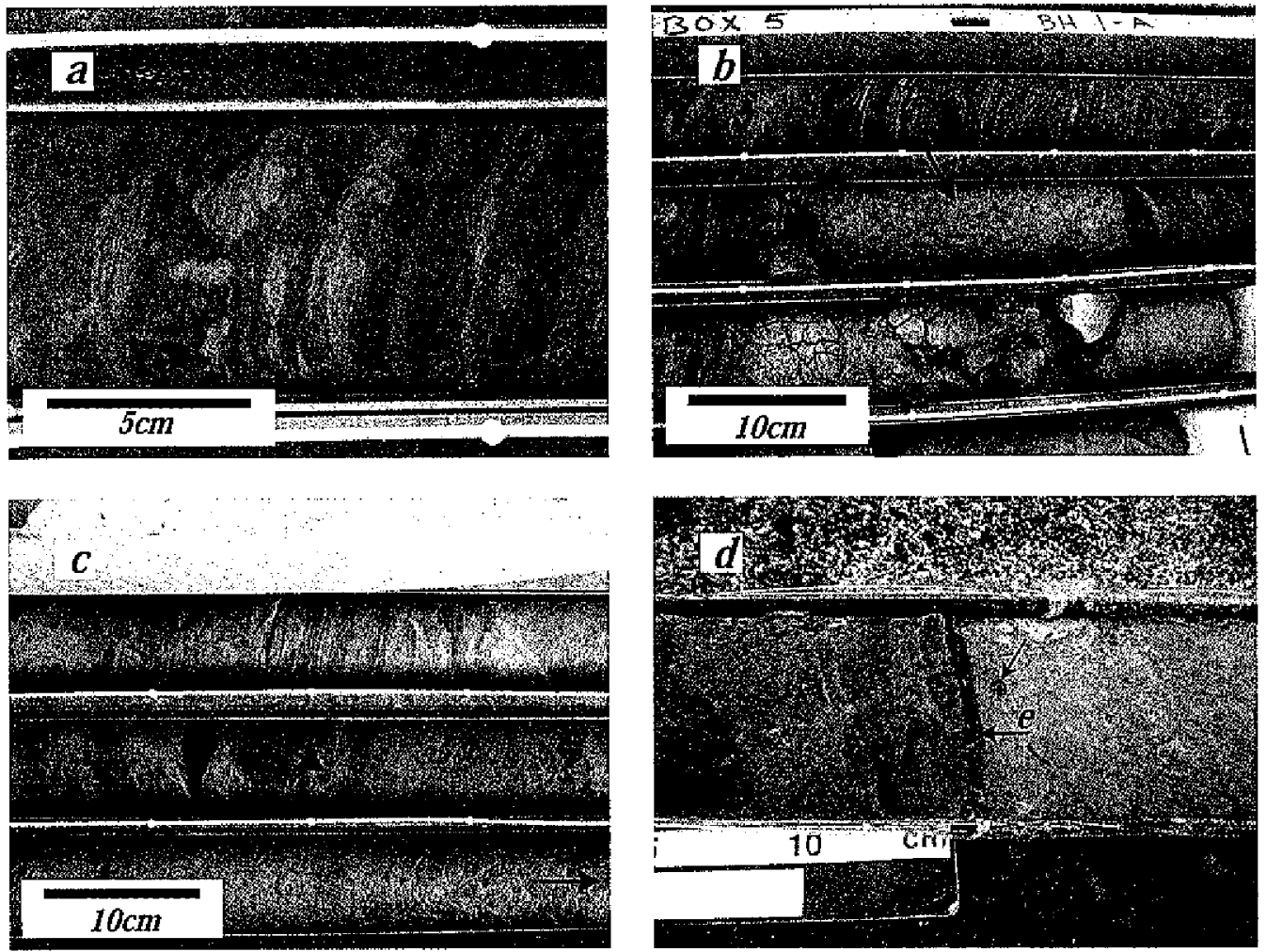

Fig. 6. Photographs showing meso- and microscopic occurrence of host and fault rocks observed in the cores from both northern and southern well. (a) Occurrence of sandy siltstone in host rocks in the Chinshui Formation. Textures of bioturvation shown in the photograph are common characteristics in the sedimentary rocks in the Chinshui Formation. (b) Occurrence of the N-MFZ-1 fracture zone at the depth ranging from 224.55 to $224.75 \mathrm{~m}$ in the core recovered from the northern borehole. Note sharp contact of water rich fault rocks with undeformed host rocks. (c) Occurrence of the N-MFZ-2 fracture zone (random fabric fault breccia) at 329. $65 \mathrm{~m}$ depth. Thin slip zone $(7 \mathrm{~mm})$ indicated by an arrow bounds the $\mathrm{N}$ MFZ-2 fracture zone and undamaged host rocks. (d) Photograph showing the thin black layer observed in N-LFZ-2 fracture zone, and "core and rim' texture of the charcoal originated from organic material in the sedimentary rocks. (e) Microscopic occurrence of thin black layer. Most of the materials are composed of oriented clay particles. (f) Occurrence of the foliated fault breccia observed on the half-cut slab at $173 \mathrm{~m}$ depth in the S-MFZ fracture zone. Scale length $10 \mathrm{~cm}$. (g) Occurrence of the extremely fragile ultracataclasite observed in the bottom of the S-MFZ fracture zone $(177 \mathrm{~m})$. (h) Microscopic occurrence of ultracataclasite. Note that many 'reworked' grains of ultracataclasite are involved. 

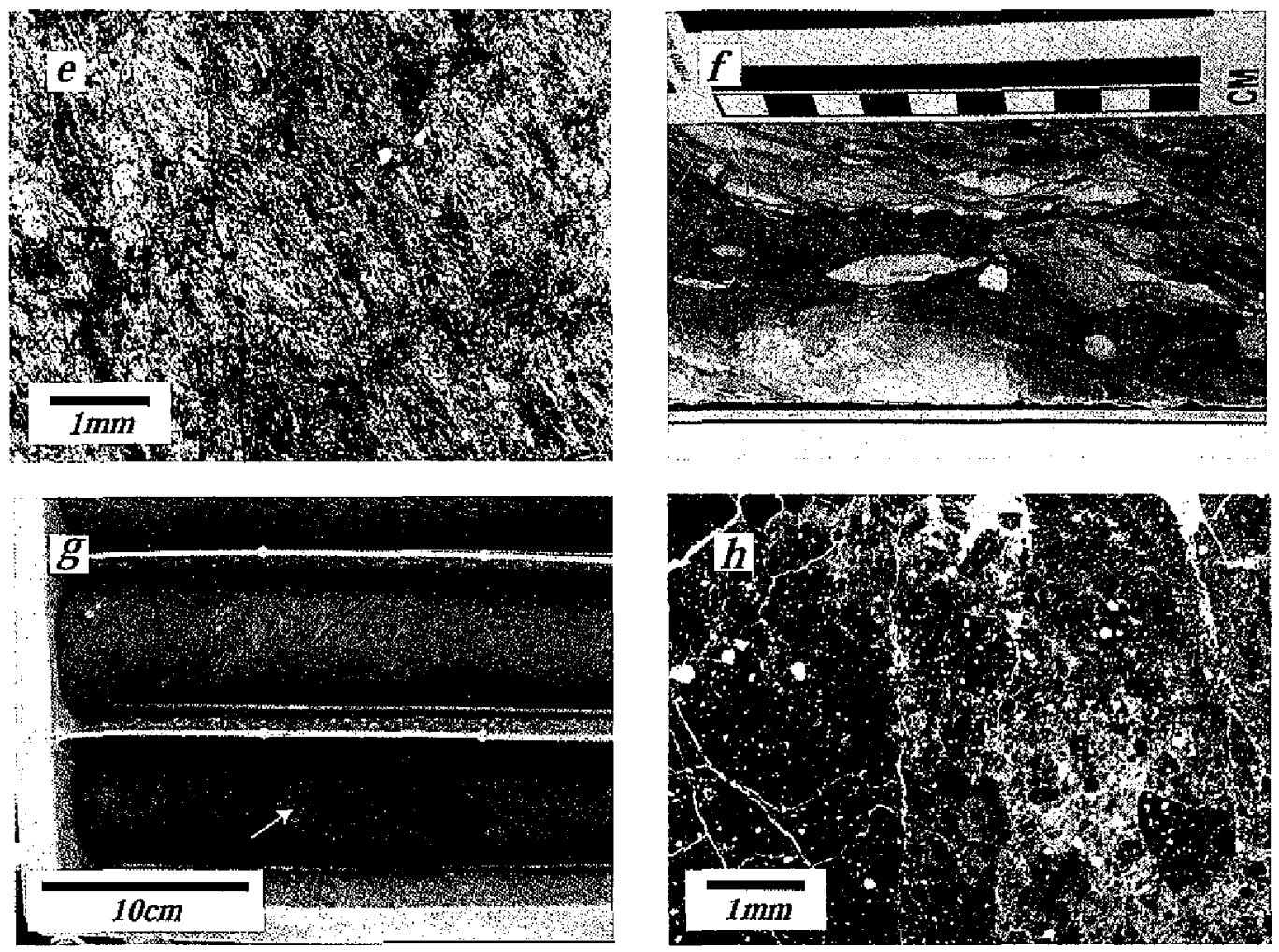

(Fig. 6. continued)

$(211.20 \mathrm{~m})$. The light gray and brown colored layer (denoted as S-LFZ in Fig. 5, $179.9 \mathrm{~m}$ to $183.2 \mathrm{~m}$ depth) is involved in the Toukoshan Formation. This layer ought to be examined microscopically to clarify whether these are fault rocks or solely a layer of surface soil involved in the Toukoshan Formation.

\section{GEOPHYSICAL BOREHOLE LOGGING}

The apparatus used for geophysical logging in both northern and southern wells are summarized in Table 1. First, geophysical logging was performed with temporal casing because both northern and southern boreholes are extremely unstable as many fragile fracture zones have developed. Some data were obtained through open-hole logging, but these contain many "data-lacking" portions, being difficult to compare with those by cased hole logging. Data sampling interval for each apparatus is $2 \mathrm{~cm}$ at logging velocity of about 5 to $7 \mathrm{~m}$ per minute. The results are combined with geological columnar section as shown in Fig. 7.

Among fracture zones in the northern borehole, two fracture zones, N-MFZ-1 and -2, are the possible spots for rupture surfaces activated by the 1999 Chi-Chi earthquake, based not only on detailed examinations of fault rocks mentioned above but also extrapolations of dips and locations of surface rupture along with the rupture trace beneath the surface resulted from 


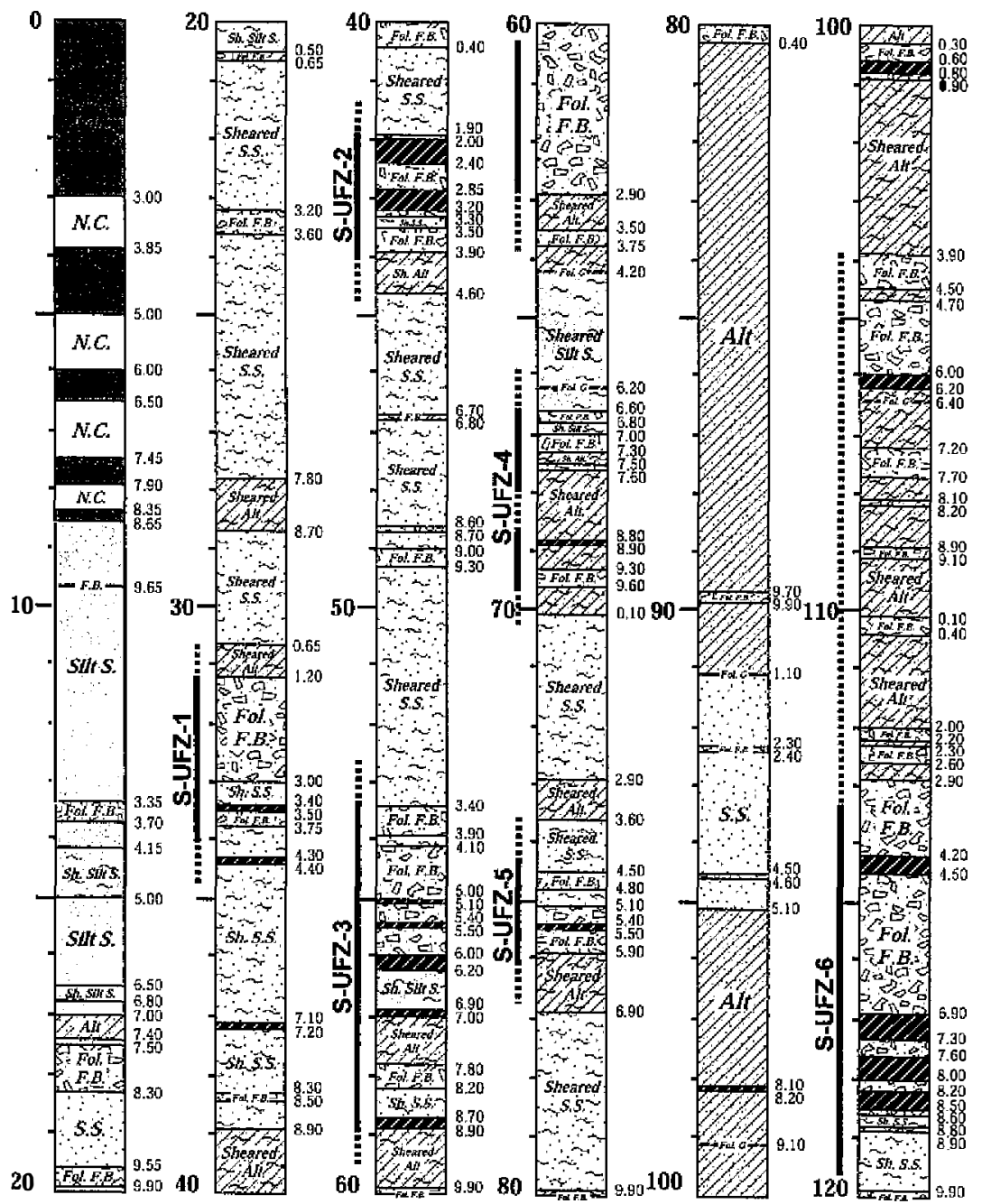

\section{Southern Borehole CLF-2 1/2}

Fig. 5. Columnar section showing lithology and fault rock distribution of the core (CLF-2) recovered from the southern (Nantou) well. Legends are the same as those in Fig. 4.

the shallow seismic reflection survey (Wang et al. 2002).

Results of temperature log show that the geothermal gradient is $<10^{\circ} \mathrm{C} / \mathrm{km}$ from surface to bottom, although this is not a concrete data because of the effect of drilling fluids. Small temperature increase $\left(<0.15^{\circ} \mathrm{C}\right)$ is observed in relatively broad extent from $280 \mathrm{~m}$ to $340 \mathrm{~m}$, which corresponds to N-MFZ-2 fracture zone (A in Fig. 7a). Results of neutron and neutron 



\section{Southern Borehole CLF-2 2/2}

(Fig. 5. continued)

porosity log show heavy fluctuations in the depth from surface to $230 \mathrm{~m}$, possibly because of irregular diameter of the well. However, these data become stable below the depth of $230 \mathrm{~m}$. In this depth range, the trend of neutron (neutron porosity) data is lower (higher) in N-MFZ-2 (B in Fig. 7a) and N-LFZ-3. Results of porosity and density log show that considerable fluctuations in these data can be observed above N-MFZ-1 fracture zone (around $225 \mathrm{~m}$ depth), whereas little change can be recognized at N-MFZ-2 (around $330 \mathrm{~m}$ depth) (Fig. 7a). The trend of natural gamma shows that it is lower above around $230 \mathrm{~m}$, and higher below that ( $\mathrm{C}$ in Fig. 7a), although the rend seems to be independent from the mode of fracture zone distribution. 
At the southern borehole, most of the core materials show flow deformation and the boundaries between fault rocks and surrounding host rocks are gradual. The temperature log shows that the geothermal gradient in southern borehole is also $<10^{\circ} \mathrm{C} / \mathrm{km}$, which is similar to the northern borehole. Smail and broad temperature bulge $\left(0.4^{\circ} \mathrm{C}\right)$ exists, as good as the northern borehole, at the depth of $160 \mathrm{~m}$ to $185 \mathrm{~m}$ where S-MFZ and S-LFZ shear zones are present (A in Fig. 7b). The density and porosity logs indicate a considerable and sudden change at the depth around $180 \mathrm{~m}$ (B in Fig. 7b), which correspond to the bottom of gray / brown material intervened by gravel layers (S-LFZ in Fig. 5). Other data including natural gamma, caliper, single point resistivity short-, long-normal resistivity seem to be arbitrary to the mode of fault rock distribution and lithofacies.

\section{DISCUSSION AND PRELIMINARY CONCLUSION}

Among many fracture zones in the northern borehole, two fracture zones, N-MFZ-1 and 2 , are the possible spots for rupture surfaces activated by the 1999 Chi-Chi earthquake. (1) The rupture trace beneath the surface was deduced from the location of surface rupture close to the northern drilling site and shallow seismic reflection images passing through a depth of $225 \mathrm{~m}$ (Wang et al. 2002). (2) The fracture zone at $225 \mathrm{~m}$ depth (N-MFZ-1) contains up to 45 vol.\% of water, and (3) the neutron and density profiles estimated from geophysical logging show considerable fluctuations above $225 \mathrm{~m}$ whereas the data are stable below. These three characteristics suggest that N-MFZ-1, a $20 \mathrm{~cm}$ thick fault breccia zone at depth of $225 \mathrm{~m}$, is the main slip zone for the 1999 Chi-Chi earthquake. However, the facts that the N-MFZ-2 fracture zone is much wider $(>10 \mathrm{~m}$ ) than N-MFZ-1 and the broad temperature rise in N-MFZ-2 suggest that the heat generation during co-seismic slip or post seismic hydrothermal fluid influx from deep beneath N-MFZ-2. Therefore, our tentative conclusion is that both N-MFZ-1 and -2 zones were activated during the 1999 Chi-Chi earthquake. If this is the case, the N-MFZ-2 fracture zone could be the major fault and the N-MFZ-1 fracture zone seems to be activated as a new breaching fault, which transferred large displacements to the surface. The crust above N-MFZ-1 would have been totally distorted by the earthquake, causing the unstable nature of

Table 1. Specifications of geophysical borehole logging.

9057: Natural Gamma, Newtron Porosity

9035: Density

9310: Full waveform sonic

Measurements in open borehole

9042: Fluid conductivity, Temperature

0018: Caliper

8057: same as 9057 except Newtron porosity measurement *

* Due to instability of the borehole. 




Fig. 7. Comparison between geological columnar sections and the geophysical logging results: (a) northern well, and (b) southern well. See text for explanations of abbreviations of ' $A$ ', ' $B$ ' and ' $C$ '. 


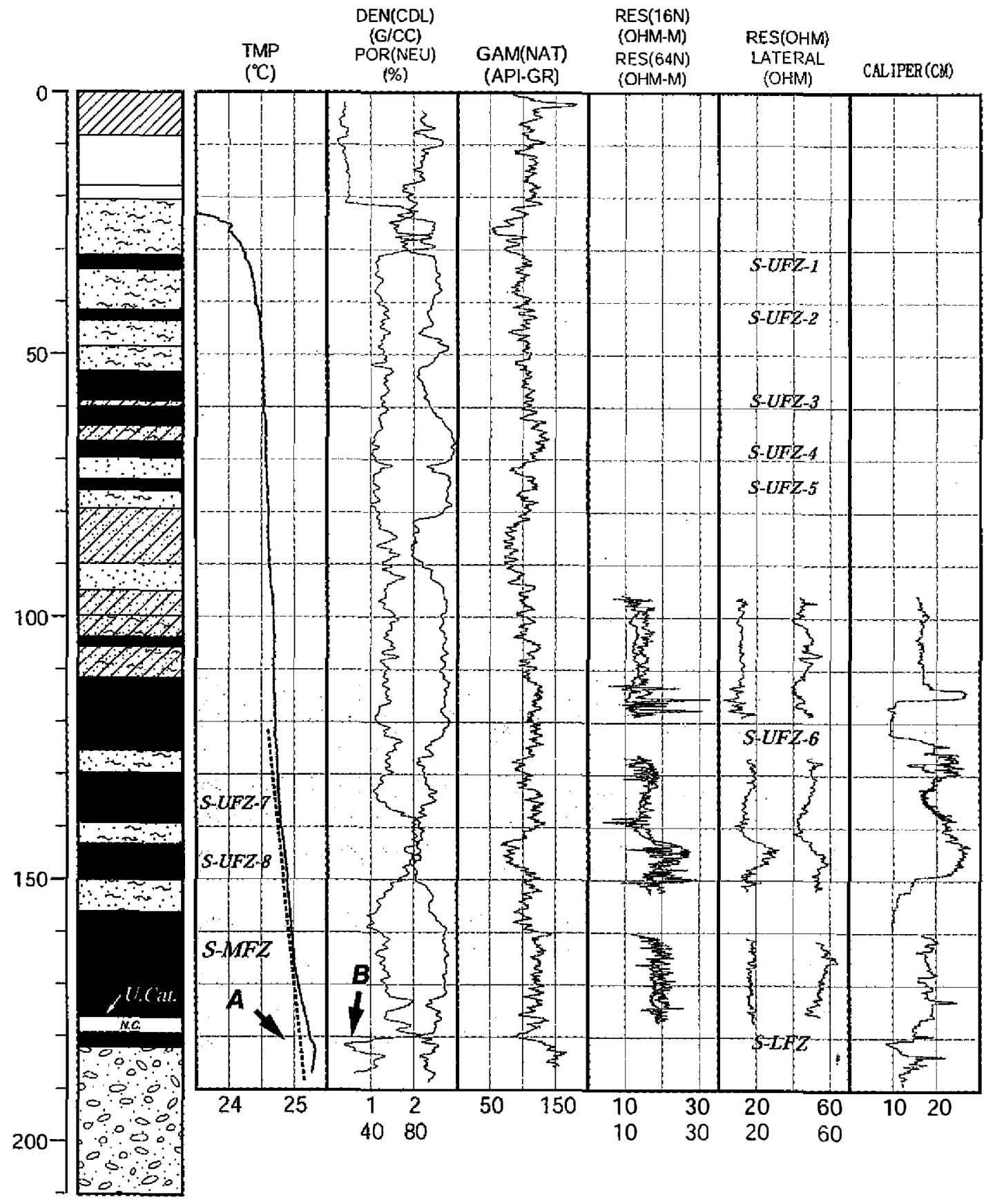

(Fig. 7. continued) 
crust shallower than N-MFZ-1 as suggested by seismic reflection neutron and density log data.

The offset of surface rupture is about $9 \mathrm{~m}$ at the northern portion along the Chelungpu fault. Assuming most of the slip is concentrated along N-MFZ-1, the narrow fault breccia zone at the $225 \mathrm{~m}$ depth, the strain of this zone caused by the earthquake is up to 28.6. The duration of the slip is estimated to be about 10 seconds by the seismic records in the northern region, thus the averaged shear strain rate is about 2.9 /s. This shear strain rate can hardly be reproduced in triaxial experimental apparatus. Thus, rate-dependent textures between material and experimental samples should be somehow compared by using, for example, rotary shear apparatus.

The prominent characteristics of the fault zones in the core from northern well are that most of the fracture zones are dominantly composed of random fabric fault breccia. Fault gouge (ultracataclasite) is found only in thin slip zones. The combination of thin slip zone plus dilatant random fabric fault breccia was also found in the Nojima fault zone at the depth of 625 $\mathrm{m}$ and $1140 \mathrm{~m}$, which were activated during the 1995 Hyogo-ken Nanbu Earthquake (Tanaka et al. 2001a; Tanaka et al. 2001b). These zones were also clearly recognized by borehole geophysical logging (Ito et al. 1996; Kiguchi et al. 2001; Ikeda 2001). Similar combination of fault rocks was also described in the ancient fault zone along the San Andreas Fault System (Punchbowl fault; Chester et al. 1993), East Fork and White Rock faults in central United States (Goddard and Evans 1995). Such combination of fault rocks would be formed by coseismic, high velocity slip as described in previous papers. Therefore, the combination of fault rocks has a potential to be a rough measure of slip velocity of the fault zone. This issue will be further discussed in the future after the examination of deformed and alternated microstructures and measurements of viscosity, elasticity and yield strengths by experimental methods for the host and fault rocks in the core.

Results of shallow seismic reflection survey indicate that the rupture surface activated by the 1999 Chi-Chi earthquake in the southern borehole lies between the Chinshui and Toukoshan Formations at the depth around $180 \mathrm{~m}$, where the S-MFZ and the S-LFZ fracture zones are distributed. The preliminary meso- and microscopic examinations indicate that the S-MFZ is composed of typical foliated fault breccia/gouge and thin ultracataclasites. The foliated fault gouge shows a lamina flow textures, indicating that the fabric was formed by flow dominant deformation with small Reynolds' Number $(\operatorname{Re}<1.0)$. This suggests that the foliated fault gouge had been formed during post-and/or interseismic periods. Although Otsuki and Monzawa (2001) reported that ultracataclasite in S-MFZ is partly molten, further examination is necessary to clarify whether the whole or part of ultracataclasite layer was surely reworked during the Chi-Chi earthquake. Small and broad temperature rise $\left(0.4^{\circ} \mathrm{C}\right)$ with sudden decrease in porosity at S-LFZ may be related to shear heating or fluid flow occurred at the vicinity of SLFZ, rather than S-MFZ. This implies that S-LFZ could also be the possible fracture zone activated by the Chi-Chi earthquake.

The offset of earthquake surface rupture at the southern portion of the Chelungpu fault was about $1.5 \mathrm{~m}$. However, the strain and strain rate are difficult to estimate because they involve significant errors unless the thickness of the slip layer activated by the Chi-Chi earthquake can somehow be accurately estimated, even if a part of the ultracataclasite (total $2 \mathrm{~m}$ 
thick) layer is assumed to be a slip zone of the Chi-Chi earthquake. This is a pending question for geologists and should be clarified in the near future, because precise seismic records are available, which show the duration of the slip motion is about 25 seconds in the southern region of the Chelungpu fault.

Problems of thermal anomaly in the fault zone are roughly discussed here. In the core from the northern borehole, there is little evidence for frictional melting even in the major fracture zones (N-MFZ-1 and -2). Thus, necessary parameters for estimation of frictional heating would be restricted since large strain and strain rate are inferred from core observation in the northern borehole. The small and broad temperature rise $\left(<0.15^{\circ} \mathrm{C}\right)$ in the N-MFZ-2 fracture zone is likely resulted from both or either frictional heating and/or hydrothermal fluid influx as mentioned previously.

In contrast, $2 \mathrm{~m}$ thick, black colored ultracataclasite / pseudotachylite layers observed in the S-MFZ fracture zone in the southern borehole would be a result of high velocity frictional slip and thus, evidence of heat generation. The fact that broad temperature rise in S-LFZ $\left(0.4^{\circ} \mathrm{C}\right.$ maximum) suggest the frictional heat generation or hydrothermal fluid flow during coand/or post seismic'stage. However, unlike N-MFZ-2 in the northern borehole, the zone of temperature rise corresponds to that of sudden decrease in neutron porosity. The data may be preferentially explained by the shear heating hypothesis rather than that of hydrothermal fluid influx, although quality of the data is not good enough. Therefore, there are two possible slip zones, either or both were activated during the Chi-Chi earthquake, which are the ultracataclasite layers at the bottom of S-MFZ and gray/brown layer of S-LFZ. However, it is unlikely that the whole zones of ulmacataclasite or gray/brown clay layer are products of co-seismic failure by the Chi-Chi earthquake. One possible method to recognize the exact position and thickness of active slip layer in such zones is to explore the evidence of recent heat generation.

Among several possible methods, charcoal contained in sedimentary and fault rocks is one of the potential heat source, since organic materials might be decomposed to charcoal by thermal effects (Sakaguchi, personal comm.). The Chinshui Formation contains abundant organic materials in which most of them are composed of wooden fragments. Some of them within the fault zones show "core and rim" texture (Fig. 6e), in which the core contains black colored organic material, while the rim contains a brown colored material suggesting partial melting and diffusion of the core material. Such decomposition of the organic material in the fault zone should be clarified by the methods of organic chemistry as well as ${ }^{14} \mathrm{C}$ method and measurements of vitrinite reflectance.

There are many important issues for improving our knowledge of the architecture and dynamic behavior of the active fault zone, which would be realized through core-material analysis obtained by core drilling in the Chelungpu fault zone. For example, the mode of distribution and the role of fault zone rocks, deformation history, permeability and water-rock chemical interaction in the fault zone, physical properties such as density, porosity, elastic wave velocity and rheological behavior of fault zone materials. Valuable results and discussions would be expected at the symposium as many researchers participating the sampling party. Detailed information, including photographs of the sites and cores, columnar sections, daily reports of drilling and schedules for future symposium can be obtained from the following website, http://www2.rcep.dpri.kyoto-u.ac.jp/ moriChelungpuDrilling 
Acknowledgements This research was supported by MEXT, Japan under grant "Research program for earthquake rupture in and around the Philippine Sea plate". Our sincere gratitude goes to Prof. Y. B. Tsai (National Central University), Prof. M. Zoback (Stanford University), Dr. J. H. Wang (Academia Sinica) and Prof. G. Kimura (University of Tokyo) for understanding and/or directing the project. We deeply thank Dr. K. A. Lin and S. T. Huang, EDRI, CPC for their cooperation of core processing at their laboratory. Valuable discussions with Prof. J. Mori (Kyoto University) and Prof. K. Ma (National Central University) were appreciated. Thanks are extended to students of University of Tokyo, National Central University and Utah State University for their great help for various kinds of site jobs. We are grateful to many researchers who contributed much effort to this joint project.

\section{REFERENCES}

Ando, M., 2001: Geological, and geophysical studies of Nojima fault from drilling: An outline of the Nojima Fault Zone Probe. The Island Arc., 10, 206-214.

Ando, M., 2002: Overview and purpose of the active fault prove at the Atotsugawa fault system - observations inside and outside a $480 \mathrm{~m}$ tunnel throughout a subsidiary fault. Geophys. Res. Lett. (in review)

Angelier, J., H. T. Chu, and J. C. Lee, 1997: Shear concentration in a collision zone: Kinematics of the Chishang Fault as revealed by outcrop scale quantification of active faulting, Longitudinal Valley, eastern Taiwan. Tectonophysics, 274, 117-144.

Chester, F. M., J. P. Evans, and R. L. Biegel, 1993: Internal structure and weakening mechanisms of the San Andreas Fault. J. Geophys. Res., 98, 771-786.

Goddard, and Evans, 1995: Chemical changes and fluid-rock interaction in faults of crystalline thrust sheets, northwestern Wyoming, U.S.A.. J. Structural Geology, 17, 533-547.

Ho, C. S., 1997: Explanatory text of the geologic map of Taiwan, 192pp., published by Central Geological Survey, The ministry of economic affairs Taiwan, ROC.

Hung, J. H., S. T. Huang, and J. C. Wu, 2001: Lithofacies and biostratigraphy of the core from the boreholes drilled through the Chelungpu fault, ICDP Workshop on Drilling the Chelungpu Fault, Taiwan.

Ikeda, R., 2001: Outline of the fault zone drilling project by NIED in the vicinity of the 1995 Hyogo-ken Nanbu earthquake, Japan. The Island Arc., 10, 199-205.

Ito, H., Y. Kuwahara, T. Miyazaki, O. Nishizawa, T. Kiguchi, K. Fujimoto, T. Ohtani, H. Tanaka, T. Higuchi, S. Agar, A. Brie, and Y. Yamamoto, 1996: Deep structure of the Nojima fault investigated at drill hole penetrating the fault surface (in Japanese with English abstract). Geophys. Explor., 49, 522-535.

Kiguchi, T., H. Ito, Y. Kawahara and T. Miyazaki, 2001: Estimating the permeability of the Nojima fault zone by a hydrophone vertical seismic profiling experiment. The Island Arc., 10, 348-356.

Lallemand, S., 2000: Was the 1999 Chichi earthquake in Taiwan a "subduction earthquake"?. $T A O, 11,709-720$.

Ma, K. F., C. T. Lee, and Y. B. Tsai, 1999: The Chichi Taiwan earthquake; large surface 
displacements on an inland thrust fault. EOS, 80, 605.

Ma, K. F., T. R. Song, S. J. Lee, and H. I. Wu, 2000: Spatial slip distribution of the September 21, 1999, Chichi, Taiwan earthquake (Mw 7.6) - Inverted from teleseismic data. Geophys. Res. Lett., 27, 3417-3420.

Ohtsuki, K., and N. Monzawa, 2001: Contrasting fault rocks from two boreholes penetrating Chelungpu fault, Taiwan, ICDP Workshop on Drilling the Chelungpu Fault, Taiwan.

Seno, T., 2000: The 21 September 1999 Chichi earthquake in Taiwan: Implications for Tsunami earthquakes. TAO, 11, 701-708.

Sibson, R. H., 1977: Fault rocks and fault mechanisms. J. Geological Society of London, 133, 191-213.

Suppe, J., 1981: Mechanics of mountain building and metamorphism in Taiwan. Geol. Soc. China, 4, 67-89.

Suppe, J., 1985: Principles of structural geology, Prentice Hall, Englewood Cliffs, 537 pp.

Tanaka, H., 1992: Cataclastic liniations. J. Structural Geology, 14, 1239-1252.

Tanaka, H., N. Uehara, and T. Itaya, 1995: Timing of the cataclastic deformation along the Akashi Tectonic Line, central Japan. Contributions to Mineralogy and Petrology, 920, 150-158.

Tanaka, H., K. Fujimoto, T. Ohtani, and H. Ito, 2001 a: Structural and chemical characterization of shear zones in the freshly activated Nojima fault, Awaji Island, southwest Japan. J. Geophys. Res., 106, 8789-8810.

Tanaka, H., S. Hinoki, K. Kosaka, A. Lin, K. Takemura, A. Murata, and T. Miyata, 2001b: Deformation mechanisms and fluid behavior in a shallow, brittle fault zone during coseismic and interseismic periods: Results from drill core penetrating the Nojima Fault, Japan. The Island Arc., 10, 381-391.

Tsai, Y. B., and M. W. Hwang, 1999: Strong ground motion characteristics of the Chichi, Taiwan earthquake of September 21, 1999. Report to NSC.

Wang, C. Y., C. H. Chang, and H. Y. Yen, 2000: An interpretation of the 1999 Chichi earthquake in Taiwan based on the thin-skinned thrust model. TAO, 11, 609-630.

Wang, C. Y., H. Tanaka, J. Chou, C. C. Chen, and J. H. Hong, 2002: Shallow reflection seismics aiding geological drilling into the Chelungpu fault after the 1999 Chichi earthquake, Taiwan. TAO, 13, 153-170.

Wang, J. H., R. D. Hwang, B. S. Hwang, K. C. Chen, W. G. Hwang, and T. M. Chang, 2000: Proceedings of International Workshop on Seismotectonics at the Subduction Zone November 29-December 1, 1999, Tsukuba, Japan, 351-360.

Wu, F. T., R. J. Rau, and D. Salzberg, 1997: Taiwan orogeny: thin-skinned or lithospheric collision?. Tectonophysics, 274, 191-220. 